\title{
MODEL OF INCREASING CORPORATE VALUE BASED ON GOOD CORPORATE GOVERNANCE IN MANUFACTURING COMPANIES LISTED ON THE INDONESIA STOCK EXCHANGE In 2012-2016
}

\author{
Alfiatul Wardah ${ }^{1 *}$, Nunung Ghoniyah ${ }^{2 *}$
}

\begin{tabular}{l}
\hline * Affiliation: \\
${ }^{1}$ PNPM Kemendagri, \\
Batang, Indonesia \\
email: \\
Alfiatulwardah@ gmail.com \\
${ }^{2}$ Lecturer of Post Graduate \\
Student of Management, \\
Universitas Islam Sultan \\
Agung, Indonesia \\
email: \\
Nunung@ unissula.ac.id
\end{tabular}

Nunung@unissula.ac.id

\begin{abstract}
:
This studyaims to analyze the role of Good Corporate Governance(GCG) as a moderating variable in increasing corporate value in manufacturing companies with variables of Corporate Social Responsibility (CSR) disclosure, Profitability, Intellectual Capital(VAICTM) with moderating variables of Good Corporate Governance (GCG) proxied institutional ownership in manufacturing companies listed on the Stock Exchange in 2012-2016. This study is included in a causative study. The population of this study is a manufacturing company listed on the Stock Exchange in 2012-2016 by using purposive sampling technique. There are 25 companies that meet the criteria as a sample so that the 110 data samples were tested using the eviews 10 student application. The results of this study state that the disclosure of Corporate Social Responsibility (CSR) has a significant positive effect on corporate value, profitability has a significant positive effect on corporate value, Intellectual capital (VAIC ${ }^{\mathrm{TM}}$ ) has a positive and insignificant effect on the value of the company, the Corporate Social Responsibility (CSR) disclosure moderated by institutional ownership has a significant negative effect on the corporate value. With more than 50\% institutional ownership, the possibility of a public response to CSR disclosure is low, profitability moderated by institutional ownership has no significant positive effect on corporate value, intellectual capital $\left(\mathrm{VAIC}^{\mathrm{TM}}\right)$ moderated by negative institutional ownership are not significant. In the findings of this study, VAIC ${ }^{\mathrm{TM}}$ did not have a significant effect on the corporate value so VAIC ${ }^{\mathrm{TM}}$ was considered not important. The absence of additional performance due to the absence of standards for measuring intellectual capital in Indonesia. The market may appreciate other factors such as profit and other fundamental factors.
\end{abstract}

Keywords: Corporate Social Responsibility (CSR), profitability, intellectual capital $\quad\left(\mathrm{VAIC}^{\mathrm{TM}}\right)$, Good Corporate Governance (GCG), Corporate Value. 


\section{INTRODUCTION}

The purpose of the company in the long term is to maximize profit, and improve the welfare of shareholders. A good company is a company that is able to maximize the potential both in financial and non-financial potential that can increase the corporate.

The corporate value is considered very important if it is good, it will be the main attraction of an investor to invest and will also reflect the prosperity of its shareholders, a high corporate value can be seen from the measurement of financial performance. Through financial reviews, investors can decide whether they will invest or not in the company. Therefore, the company must always improve financial performance so that its shares remain and always be the choice of investors (Tendi Haruman, 2008). Several factors can influence the value of the company, namely disclosure of Corporate Social Responsibility (CSR), Profitability and also Intellectual Capital (VAIC ${ }^{\mathrm{TM}}$ ).

The more companies carry out their social responsibility, the better the image of the company in the community can attract investors to invest in the company. Several previous studies on CSR disclosure have been carried out by several researchers, this can be seen from the results of a study conducted by Boonlert Jitmaneeroj (2018), Siti Sapia (2015), stated that disclosure CSR has a significant positive effect on corporate value. Besides that, there are contradictions of the research conducted by Vicenta Lima Crisostomo (2011) and Laras and Basuki Hadiprajitno (2012) who stated that CSR does not have a significant positive effect on firm value.

Profitability can influence the value of shares because if the profitability generated is high reflects that the company's performance looks good. Therefore, if the profitability produced is good, it will drive the higher corporate value. Some studies on profitability conducted by Ria Nofrita (2013), Alfredo (2011) and Rika (2010), Bayu (2017), Amalia and Daniel (2017) and Gusti and Maria (2013) with the results of research that profitability has a positive effect on corporate value while the contradiction of the results of research conducted by Irvan (2014) which states that profitability does not have a significant effect on corporate value.

Intellectual Capital has a role in increasing the value of the company, if the company is able to utilize its intellectual capital efficiently so that it can create value added for the company, the greater the value of intellectual capital (VAIC ${ }^{\mathrm{TM}}$ ) that is used, it will be able to increase competitive advantages that can contribute to the increase in corporate value. Previous research on intellectual capital (VAIC ${ }^{\mathrm{TM}}$ ) with a significant positive effect was made by Restuti (2014), Rashid Saed. at.al (2013), Noorlailie Soewarno (2011), but there is also a contradiction in the research conducted by Desak Sri Wedastuti (2014) which states that intellectual capital does not have a significant effect on corporate value. 


\section{Table 1.1}

\section{Research Gap of Corporate Value}

\begin{tabular}{|l|l|l|l|l|}
\hline No & CSR & Profitability & Intellectual Capital & Result \\
\hline 1 & $\begin{array}{l}\text { Boonlert Jitmaneeroj (2018),Siti Sapia } \\
(2015) \\
\text { Nahda and Harjito(2011) }\end{array}$ & $\begin{array}{l}\text { Bayu (2017), Amalia and } \\
\text { Daniel (2017) also Gusti } \\
\text { and Maria (2013) }\end{array}$ & $\begin{array}{l}\text { Restuti (2014), } \\
\text { Rashid Saed. at.al } \\
\text { (2013), Noorlailie } \\
\text { Soewarno(2011) }\end{array}$ & $\begin{array}{l}\text { Significantly } \\
\text { affect }\end{array}$ \\
\hline 2 & $\begin{array}{l}\text { Vicenta Lima Crisostomo (2011), } \\
\text { Laras and Basuki Hadiprajitno (2012) }\end{array}$ & irvan (2014) & $\begin{array}{l}\text { Desak Wedastuti } \\
(2014)\end{array}$ & $\begin{array}{l}\text { Significantly } \\
\text { not affect }\end{array}$ \\
\hline
\end{tabular}

Based on the contradiction between inconsistencies among several studies regarding CSR disclosure, profitability, Intellectual Capital with corporate values, the researchers tried to add one of the variables that mediated the relationship between CSR disclosure, profitability, Intellectual Capital and corporate value, this is believed to be a rule able to lead to all existing elements in the company to achieve the goals set by the company. Based on the description of gap phenomena and research gap regarding increasing corporate value, the problem in this study is "How Corporate Social Responsibility (CSR) Disclosure, Profitability, and Intellectual Capital (VAIC ${ }^{\mathrm{TM}}$ ) Affects Company Values with Good Corporate Governance (GCG) as Moderating Variables".

\section{LITERATURE REVIEW}

\section{Corporate Value}

Areflection of the prosperity of its shareholders can be seen from the increase in stock prices. Management seeks to make the right policy so that investors are always satisfied with the increase in the price of their shares. Various policies are taken by management to increase the prosperity of owners and shareholders which can be seen from the stock price (Bringham \& Houston, 2006: 19). Corporate value according to (Salvatore, 2005) is the view of the success of a company that has a relationship with stock prices. The company is considered good by investors if the stock price is high so investors assume that the company's performance is good and has great prospects in the future. The main purpose of the company according to the company theory is to be able to maximize wealth or corporate value. Whereas According to (Noerirawan, 2012), corporate value is a reflection of the condition of a company in its performance to increase stock prices in the form of trust from the public to become investors by buying shares. The measurement of company value used in this study is Tobin's Q which can be calculated by comparing the ratio of market value of company shares with the book value of company equity.

\section{Corporate Social Responsibility (CSR) Disclosure}

CSR is a form of corporate responsibility to the community, environment, government, and social, as the company's commitment to improve everything (Kotler and Nancy, 2005). In the book of (rahman, 2008) entitled 'the world business council for sustainable development', CSR disclosure is a business commitment to sustainable economic development and in 
collaboration with company employees, the family of company employees and communities around the environment to improve the quality of life.

The indicators of CSR disclosure measurement in this study were adopted from the study of Sembiring (2005) which consisted of 6 (six) themes with 84 disclosure items, economics, energy, employment, human rights, social, community and product responsibility.

According to Chuk William (2001: 123) in (Resturiany: 2011), the company's goal of CSR disclosure must have a clear mission and motivation that will have an impact on the social, economic and stakeholder environment (Wibisono; 2007). Even the implementation of CSR disclosure will not guarantee the benefits of a company. The main objective of the company is to generate profits, but to survive or develop in the long term many strategies are carried out by companies such as CSR activities, so that they can provide a good image for the company in front of the society. So that the hypothesis is set as:

\section{$\mathrm{H}_{1}$ : Corporate Social Responsibility (CSR) disclosure affects corporate value}

\section{Profitability}

According to Masud (Kusuma et al, 2013: 3), profitability is the company's ability to generate profits to measure the effective level and efficiency in operations and the use of assets owned by the company. Investors and shareholders use profitability to see the benefits that investors will get the dividends.

Saidi (2004) in Martalina (2011) stated that profitability is the company's profit generated from operational activities. Every investor who buys a company's shares must aim to get a return consisting of yield and capital gains. If the higher the profit that will be generated by the company, the return expected by investors will also be higher so that the value of the company will increase to be better. In addition, according to Munawir (1995: 31) in Martalina (2011), profitability is the profits generated by companies in a certain period resulting from company activities that can be seen from the results of sales and capital. The indicators used in this study are Return on Assets (ROA). A company can be measured by the relationship between net income obtained from the sale of company products which is then divided by total assets and multiplied by one hundred percent. The hypothesis is set as follows:

\section{$\mathrm{H}_{2}$ : Profitability affects corporate value}

\section{Intellectual Capital}

According to Gunawan et al. (2013), Intellectual Capital is an asset in the form of employee knowledge, information that is intangible and not included in financial statements becomes an intangible asset. Meanwhile, according to Puspitasari (2011), Intellectual Capital is an intangible asset that becomes the company's superiority. The definitions of intellectual capital above have led some researchers to develop specific components of intellectual capital. Pulic (2001) classifies intellectual capital in value-added obtained from the difference in income (input) of the company with all costs (output). Furthermore, the value added of intellectual capital is divided into capital employed (VACA), human capital (VAHU), and structural capital (STVA). Intellectual capital is an intangible asset that is included in financial statements, recognition, and measurement. One of the ways is to expand 
the disclosure of intangible assets, that is, the disclosure of intellectual capital (Sir et.al, 2010). The hypothesis for this study is as follows:

\section{$\mathrm{H}_{3}=$ Intellectual Capital $\left(\right.$ VAIC $\left.^{T M}\right)$ affects corporate value}

\section{Good Corporate Governance (GCG)}

GCG is a direct and control system for a company so that the company's goals can be achieved optimally (Setyaningrum, 2012). GCG will affect the achievement of a company, stakeholders need a GCG mechanism to obtain clear information about the company (Tumirin, 2007). GCG can be applied on two sides, they are ethics and regulations. The things that encourage ethics (ethical driven) in the form of individual awareness as a business person in carrying out business practices that prioritize the survival of the company in the long term and do not use ways to get a momentary profit. If the GCG mechanism is implemented properly, it will improve the quality of the company's financial statements. Companies are required to have quality, accurate financial reports so that investors are easier to make investment decisions that adhere to accounting principles that are free from fraud and forgery. According to the National Committee on Corporate Governance (2004), a good corporate governance system contains five main principles, namely transparency, accountability, responsibility, independence, and fairness.

According to Herawati (2008) and Siallagan and Machfoedz (2006), the standards for measuring GCG include of managerial ownership, institutional ownership, and the size of the board of directors. The role of management leadership is as a party that unites between parties who have the same interests as managers and shareholders. In addition, institutional ownership has a role to encourage supervision of the corporate performance to the maximum. The size of the board of directors comes from outside the company that occupies the organizational structure and serves as a counterweight in making a decision. While audit quality is very important because it will produce financial reports that can be trusted by investors in making a decision (De Angelo, 198, in Kusharyanti: 2003: 25).

\section{The relationship between disclosure of Corporate Social Responsibility (CSR), Good Corporate Governance (GCG) and Corporate Value}

The function of GCG is intended to be able to regulate the relationship between parts of a company and prevent the occurrence of serious mistakes in the corporate strategy. GCG is also intended to ensure that errors that occur can be corrected quickly. On a practical level, Indonesia has GCG guidelines compiled by the national GCG policy committee. At present, companies that have implemented GCG have felt the magnitude of the benefits after they can take consistently implementing the concept. In addition, for improving performance, share prices and company image also increased. Even the credibility of the company continues to rise in order to cross national borders, both for investors, partners and creditors and other stakeholders.

Disclosure of CSR is the principle closest to GCG, from this principles can be seen that there is a significant emphasis on corporate stakeholders. As a business entity that has responsibility for the community and its environment, a company should have good actions as 
a good citizen, which is a demand for good business ethics. So that it becomes a natural thing if the company also pays attention to the importance of disclosure of CSR and value added to its stakeholders. The effect of CSR disclosure on GCG has been proven by Widyatama(2010) with the results of research that CSR disclosure has a positive effect on GCG. The hypothesis in this study is set as follows:

\section{H4 : Disclosure of Corporate Social Responsibility (CSR) affects the value of the company with Good Corporate Governance (GCG) as a moderating variable}

7. The relationship between Good Corporate Governance (GCG) and corporate value

Profitability is a description of the company's performance including financial performance, which is determined by the extent to which the company is serious in conducting good corporate governance, if the company is getting serious in implementing GCG, the company's financial performance will increase (Hamdani, 2016).

If the principles of GCG are able to be implemented properly in the company, it is expected that the company's profitability will increase. GCG is a form of regulation in the context of corporate control to produce value added and stakeholders. GCG is expected to form a transparent, clean and professional management work pattern so that profitability will increase. Nurdiana (2012) has proven that company profitability has a positive effect on GCG. The hypothesis in this study is set as follows:

\section{H5 : Profitability affect corporate value with Good Corporate Governance (GCG) as mediating variable}

8. The effect of Intellectual Capital, Good Corporate Governance (GCG) with corporate value

Intellectual capital is an intangible asset that must be managed properly so that the company's goals can be achieved optimally. According to Lukman (2003), Intellectual capital is very important for the company's sustainability in the long term because of anticipating long-term competition through professional resources, skills and good integrity, and high trust.

Intellectual capital is believed to be a driving force for the company's progress in facing competition, technology, and innovation. This must also be balanced with GCG that has a good order of all elements in the company. The hypothesis in this study is set as follows:

H6: Intellectual Capital affects corporate value with Good Corporate Governance (GCG) as a moderating variable

\section{The Empirical Model of Research}

There are $4(\mathrm{X})$ variables in this study, namely Corporate Social Responsibility (CSR) (X1), Intellectual capital (VAICTM) (X2), profitability (X3), Good Corporate Governance (GCG) (X4) that is able to affect (Y1) variables namely Corporate Value and moderating variable (Y2), namely Good Corporate Governance. 


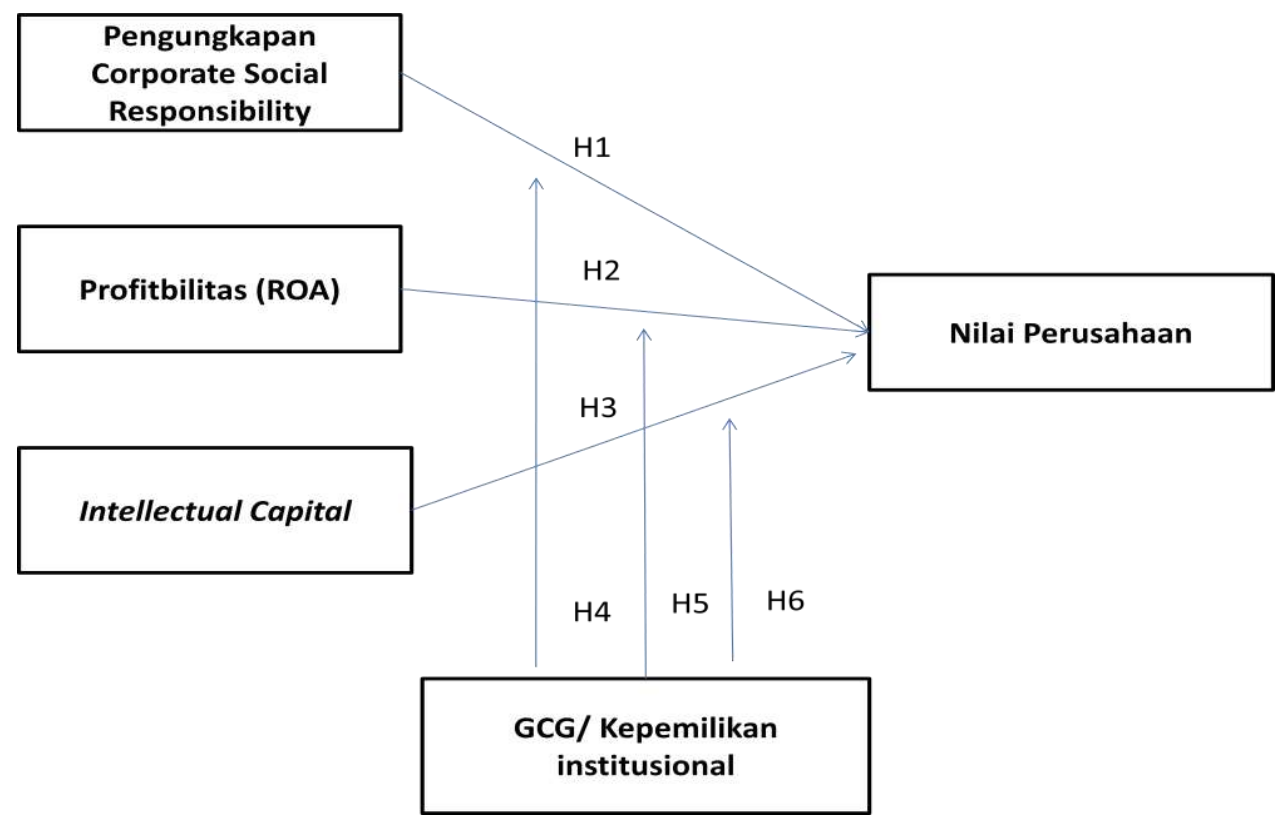

FIGURE 2.2 EMPIRICAL MODEL OF RESEARCH

\section{METHODOLOGY}

This study used type of quantitative research in the form of explanatory research with the aim of testing a theory or hypothesis from previous research. According to Asep Hermawan (2009), explanatory research is research in the form of numbers from measurement results using causal analysis or causal analysis through the submission of hypotheses. The population of this study was 22 manufacturing companies listed on the Indonesia Stock Exchange during 2012-2016 with 110 samples. The data sources used secondary data. obtained from published financial statements and other reports sourced from the Indonesia Capital Market Directory (ICMD) for 2012-2015 issued through the Indonesia Stock Exchange which was downloaded from www.idx.co.id which provides annual financial reports from each company and literatures that can support this study.

The data obtained will then be processed by using e-views 10 with the method of multiple linear regression analysis. The test steps are test data analysis, classic assumption test, hypothesis test.

\section{RESULT}

\section{Determine the Analysis of Regression Equation Model}

Based on the results of the chow test in this study, the probability value of cross-section F which is equal to 0.0000 means less than 0.05, the best model used is Fix Effect (FE) which can be seen in appendix 1. Then proceed with the second test which is Housman Test with a probability value of Cross-Section Random of 0.0050 which means less than 0.05 . Then the conclusion of the Housman Test model used is Fix Effect (FE) which can be seen in appendix 2. The Chow and Housman Test used Fix Effect (FE) models, the third test namely the Lagrange Multiplier (LM) Test was not needed. 


\section{Classic Assumption Test}

\section{a. Multicollinearity Test}

Based on the results of the multicollinearity test from table 4.7, the magnitude of the results of the correlation coefficient between the independent variables is less than 0.9. This means that there is no multicollinearity among the independent variables.

\section{Table 4.7}

The multicollinearity test results of independent variable

\begin{tabular}{|l|l|l|l|l|}
\hline & CSR & \multicolumn{1}{|c|}{ ROA } & VAIC & KPI \\
\hline CSR & & $0.0067937<0,9$ & $-0.118385<0,9$ & $-0.109017<0,9$ \\
\hline ROA & $0.067937<0,9$ & & $-0.145998<0,9$ & $0.250787<0,9$ \\
\hline VAIC & $-0.118389<0,9$ & $-0.145998<0,9$ & & $0.000439<0,9$ \\
\hline KPI & $-0.109017<0,9$ & $0.250787<0,9$ & $0.4391<0,9$ & \\
\hline
\end{tabular}

\section{b. Heteroscedasticity Test}

The heteroscedasticity test results of this study used the Fixed Effect General Least Square (GLS) model, namely by using the glejser test. With the probability values of each independent variable: X1 CSR (0.5350), X2 ROA (0.1812), X3 VAIC (0.1287), X4 KPI (0.1287). Based on the test results of the independent variables of CSR, ROA, VAIC, KPI with a probability value of more than 0.05 means that heteroscedasticity does not occur.

\section{c. Normality Test}

Based on the normality test in this study, in figure 4.1, it can be seen that the Jarque-bera value is 1.574170 and the probability value is 0.455170 , which means that the probability value is more than $<0.05$ so that the residue is normally distributed.
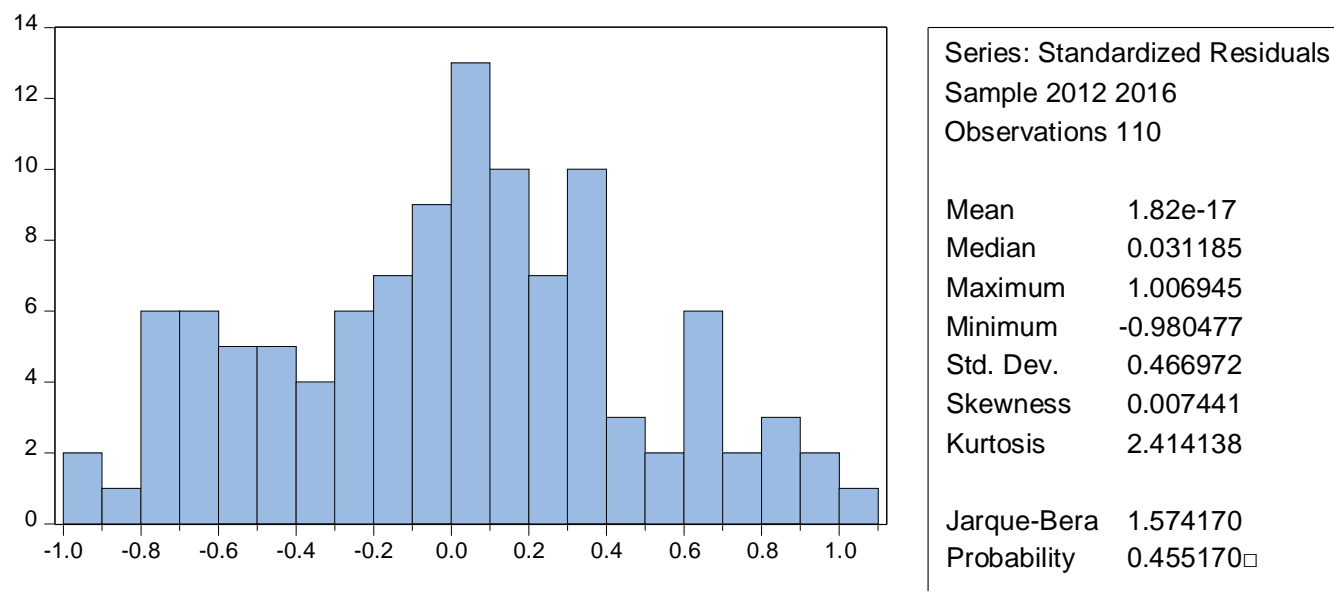

Figure 4.1

Normality Test Result

\section{d. Hypothesis Test}

After testing the classic assumption, that is, the multicolourity test, heteroscedasticity and also the normality test, then the next is testing the hypothesis by determining the estimation 
of the regression model Fixed Effect Model (FEM) after the Chow test and Housmant test using eviews 10 .

Table 4.8

Summary of Hypothesis Test of Fixed Effect Model Estimation

\begin{tabular}{crrrr}
\hline \hline — Variable & Coefficient & Std. Error & t-Statistic & Prob. \\
\hline C & 1.782249 & 0.607431 & 2.934076 & 0.0044 \\
CSR & 5.669845 & 1.727191 & 3.282697 & 0.0015 \\
ROA & 4.357388 & 1.787830 & 2.437250 & 0.0170 \\
VAIC & 0.008105 & 0.037652 & 0.215251 & 0.8301 \\
KPI & 0.854290 & 0.810835 & 1.053593 & 0.2952 \\
X1_X4 & -8.009014 & 2.332940 & -3.433013 & 0.0009 \\
X2_X4 & 0.812629 & 2.454200 & 0.331117 & 0.7414 \\
X3_X4 & -0.012164 & 0.043828 & -0.277548 & 0.7821 \\
\hline
\end{tabular}

If seen from table 4.8 that is hypothesis testing using GLS estimation test, the coefficient value of each independent variable is obtained from the dependent variable and also the independent variable on the dependent variable which is moderated, that is, with the value X1 (CSR) 0.0015, X2 (ROA) 0, 0170, X3 (VAIC) 0.8301, X4 (KPI) 0.2952, the effect of the moderating relationship among variables is X1_X4 (0,0009), X2_X4 (0.7414), X3_X4 (0.7821) Based on the results of the test hypothesis table 4.8 can be made equation:

Tobins' $_{\text {it }}=1.782+0,0015+0,0170+0,8301+02952+0,0009+0,7414+0,7821$

\section{DISCUSSION}

\section{a. The Effect of Corporate Social Responsibility (CSR) disclosure on company value}

Based on the hypothesis test results, the CSR disclosure variable has a significant positive effect on corporate value. This is in accordance with the hypothesis of $\mathrm{H}_{1}$ that is accepted. The result of this study is similar to the research conducted by Marhamah (2013), Siti Sapia (2015), and also Boonlert Jitmaneeroj (2018) which states that CSR disclosure has a significant positive effect on corporate value.

This is in accordance with the theory which states that the more companies disclose

(CSR), the value of the company will increase because the market will give a positive appreciation to companies that have made disclosures (CSR) so that it will have an impact on increasing the company's stock price (Ghoul Et al ., 2011). The more companies disclose their (CSR), the higher the value of their shares so that in the annual report, the disclosure is broader.

According to (Rika and Islakhudin, 2008), the success of a company is also determined by how much the company contributes to society and its environment so as to create mutual relations. The company needs a positive response from the community obtained because the company carries out its responsibilities in the form of (CSR) disclosure as a form of corporate responsibility to the community for its operational activities. Therefore, the role of CSR disclosure is very influential on the value of the company. Theoretically, the more companies disclose the CSR, the value of the company will increase because the market will give a 
positive appreciation to companies that have made CSR disclosures so that it will have an impact in increasing corpoate value (Ghoul Et al., 2011). The more companies disclose their CSR disclosures, the investors will usually be more interested to the company.

The results of this study are not in line with the research conducted by Vicenta Lima Crisostomo (2011) and Laras and Basuki Hadiprajitno (2012) which state that CSR disclosure does not have a significant positive effect on corporate value.

\section{b. The Effect of Profitability (ROA) on Corporate Value}

Based on the results of hypothesis testing, the profitability (ROA) variable has a significant positive effect on corporate value. This is in accordance with the $\mathrm{H} 2$ that is accepted. The result of this study is same as the research conducted by Bayu (2017), Daniel (2017), and Ria Nofrita (2013) which states that profitability has a positive but not significant effect on corporate value.

In this case, according to the theory which states that if the profits generated by the company increase, the position of the company are better. Then, the value of the company will increase when viewed in terms of asset use (Pandia, 2012).

According to (Yunita, 2012) Profitability is very important for companies to maintain their business. Profitability is able to show companies that have good prospects in the future. Profitability is very influential on the share value because if the profitability generated is high, it reflects that the company's performance looks good. Therefore, if the profitability produced is good, it will drive the corporate value higher. The higher the level of return that will be received by shareholders, it will increase the corporate value automatically.

The results of this study are not in line with the research conducted by Irvan (2014) which states that profitability does not have a significant effect on corporate value.

\section{c. The Effect of Intellectual Capital $\left(V A I C^{T M}\right)$ on Corporate Value}

Based on the results of hypothesis test, the VAIC variable has a positive and not significant effect on corporate value. This is in accordance with the $\mathrm{H}_{3}$ that is rejected. The result of this study is same as the research conducted by Noorlailie Soewarno (2011) which states that VAIC has no significant effect on corporate value.

The results of this study do not support the theory of (Firrer and William, 2003) that stated that Intellectual capital is a company's wealth that is intangible but is able to provide strength in increasing the corporate value. Information about intellectual capital can be used as information for investors (Pulic 1998, Bontis, 2001). This information is considered important for investors in making investment decisions. The disclosure of information about intellectual capital can reflect the company's performance so that it can increase value added for the company. This can make the corporate value increase through profit creation, strategy, technological innovation, as well as customer loyalty, cost reduction, and increased productivity. Intellectual Capital has a role in increasing the value of the company if the company is able to utilize its intellectual capital efficiently so that it can create value added for the company, the greater the value of intellectual capital ( $\mathrm{VAIC}^{\mathrm{TM}}$ ) that is used will be able to increase competitive advantages that can contribute to the increase in corporate value . 
The results of this study state that VAIC is not significant towards corporate value so VAIC is considered not important. This study is not in line with the research conducted by Restuti (2014), Rashid Saed. et.al. (2013), and Noorlailie Soewarno (2011) which states that VAIC has a positive effect on corporate value.

\section{d. The Effect of CSR disclosure on corporate value with GCG / institutional ownership as a moderating variable}

Based on the results of the hypothesis test of the GCG / institutional ownership variable successfully moderating the relationship between CSR disclosures, it has a significant negative effect on corporate value. This is in accordance with the hypothesis test of the $\mathrm{H} 4$ that is accepted. The result of this study is same as the research conducted by Andi (2012), Rio and Rosinta (2012), and Maria (2013) with the conclusion that GCG has a significant negative effect on corporate value so that institutional ownership weakens the relationship between CSR disclosure and corporate value.

In this case, the results of the study are not in accordance with the theory which states that CSR is the principle closest to GCG. These principles can be seen that there is a significant emphasis on corporate stakeholders. As a business entity that has responsibility for the community and its environment, a company should have good actions as a good citizen, which is a demand of good business ethics. Based on that principle, it is expected that a company can realize that in its operational activities it often results in external impacts that must be borne by stakeholders. So that it becomes a natural thing if the company also pays attention to the importance of disclosure of CSR and value added to its stakeholders (Widyatama, 2010). With the existence of institutional ownership which is more than $50 \%$, the possibility of the public response to the disclosure of CSR is low.

\section{e. The Effect of ROA on corporate value with GCG / institutional ownership as a moderating variable}

Based on the results of testing the hypothesis of the GCG variable / institutional ownership did not succeed in moderating the relationship of ROA to a corporate value which had a positive and insignificant effect on corporate value. In this case, the H5 is rejected.

The results of this study do not support the argument from (Julianto, 2012) which states that institutional ownership has an important role in corporate decision making, because the highest share ownership of the company is as a shareholder who can make policies and determine the direction of the company's progress so that good institutional ownership will affect the company's performance in increasing company profits, which in turn will increase the company's profit and affect the corporate value.

\section{f. The Effect of intellectual capital (VAIC) on corporate value with GCG / institutional ownership as a moderating variable.}

Based on the hypothesis test results, the GCG / institutional ownership variable managed to moderate the relationship between VAIC and negative and no significant effect on corporate value, this was not in accordance with H6 that is rejected. 
The results of this study do not support the theory from (Firrer and William, 2003) which states Intellectual capital which is an intangible asset that must be managed properly so that the company's goals can be achieved optimally and the corporate value increases. According to Lukman (2003), Intellectual capital is very important for the sustainability of the company in the long term because of anticipating long-term competition through professional resources, skills and good integrity, and high trust.

In the findings of this study, VAIC did not have a significant effect on corporate value so VAIC was considered insignificant. The absence of additional performance was caused by the absence of standards for measuring intellectual capital in Indonesia. The market is likely to appreciate other factors such as profits and other fundamental factors.

\section{CONCLUSION}

Based on the results of research conducted at manufacturing companies for 5 years, namely in the year 2012-2016 with 22 sample companies using the Fix Effect model (FEM) test. The independent variables are Corporate Social Responsibility, Profitability (ROA), Intellectual Capital (VAIC), with the moderating variable GCG / institutional ownership and the dependent variable that is the corporate value (Tobins, Q) with the conclusions of the research results:

1. Corporate Social Responsibility (CSR) has a significant positive effect on corporate value. This means that if there is an increase in the value of CSR disclosure, the corporate value will also increase.

2. Profitability (ROA) has a significant positive effect on corporate value. This means that if there is an increase in the value of ROA in the company, the corporate value will also increase.

3. Intellectual Capital (VAIC) has no significant positive effect on corporate value. It means that every increase in VAIC does not affect the corporate value.

4. GCG or institutional ownership as a moderating variable does not have a significant negative effect on the CSR variable on corporate value. This means that the presence of a moderating variable in GCG / institutional ownership weakens the relationship of CSR to corporate value.

5. GCG / institutional ownership as a moderating variable has a positive but not significant effect which means that it is not able to strengthen the relationship of the ROA variable to corporate value. This means that the presence of a moderating GCG/institutional ownership variable weaken the effect of ROA relations on firm value.

6. GCG/institutional ownership as a moderating variable gives a negative and not significant effect on VAIC variables on corporate value. This means that the presence of a moderating variable in GCG/institutional ownership is not able to strengthen the effect of the relationship between VAIC and corporate value. 


\section{REFERENCES}

Alghifari at.al. (2013). Effect Of Return On Assets (ROA) Againt Tobin's Q: Studies In Food And Beverage Company In Indonesia Stock Exchange Years 2007-2011. International Journal of Science and Research (IJSR) Vol. 2 No. 1.pp. 722-725. ISSN: 2319-7064.

Amalia Nur Chasanah dan Daniel Kartika Adhi. (2017). Profitabilitas, Struktur Modal dan Likuiditas Pengaruhnya Terhadap Nilai Perusahaan Pada Perusahaan Real Estate yang listed di BEI. Fokus Ekonomi.

Bontis et al. (2000). "Intellectual Capital And Business Performance In Malaysian Industries". Journal of Intellectual Capital 2000.

Boonlert Jitmaneeroj. (2018). A latent University of the Thai Chamber of Commerce Bangkok Thailand Variable Analysis of Corporate Social Responsibility and Firm Value. University of the Thai Chamber of Commerce Bangkok Thailand.

Brigham and Houston. (2004). Fundamentals of Financials Managemen. Tenth Edition. South Western. Singapore. Terjemahan A. A. Yulianto. 2006. Dasar-Dasar Manajemen Keuangan Edisi Kesepuluh. Salemba Empat. Jakarta.

Brigham dan Ehrhardt,(2005). Financial Management Theory And Practice, Eleventh Edition. Ohio: South Western Cengage Learning.

De Angelo, L.E .(1981). Auditor Size and Audit Quality Journal Of Accounting And Economics: 183-199.

Forum Corporate Governance in Indonesia. (2005). Peranan Dewan Komisaris dan Komite Audit Dalam Pelaksanaan Corporate Governance ( Tata Kelola Perusahaan). Jilid 2. FCGI. Jakarta.

Ghozali Imam, (2011), Analisis Multivariate dengan SPSS, Semarang: Badan Penerbit Universitas Diponegoro.

Ghozali Imam, (2011) Aplikasi Analisis Multivariate dengan Program IBM SPSS 19, Edisi V, Semarang : Badan Penerbit Universitas Diponegoro.

Husnan, Suad. (2001). Dasar-dasar Teori Portofolio dan Analisis Sekuritas. Edisi Ketiga. UPP AMP YKPN, Yogyakarta.

Husnan, Suad. (2001). Pembelajaran Perusahaan (Dasar-Dasar Manajemen Keuangan), Edisi III. Yogyakarta: Liberty.

Kasmir. (2010). Analisis Laporan Keuangan. Jakarta: PT Raja Grafindo Persada.

Latupono, Siti Sapia. (2015). Pengaruh Corporate Social Responcibility terhadap nilai perusahaan dengan Good Corporate Governance sebagai variabel moderating. Surabaya: Jurnal Ilmu dan Riset Akuntansi vol.4 No.8. 
Ghoul, Sadok el, Omrane Ghuedami, Chuc. Y. Kwok and Dev R. Mishra. (2011). Does Corporate Social Responcibility affect the cost of capital ? Journal Of Banking and Financial, 35(9), pp: 2388-2406.

Herawati, Vinola. (2008). Peran Praktik Corporate Governance Sebagai Variabel Moderating Variabel dari pengukuran Earning management Terhadap Nilai Perusahaan. SNA XI Pontianak.

Haruman,Tendi. (2008) : "Pengaruh struktur kepemilikan terhadap keputusan keuangan dan nilai perusahaan”. Simposium nasional akutansi XI, Pontianak.

Jusriaini. F. I. dan Rahardjo N.S, (2013). Analisis Pengaruh Profitabilitas, Kebijakan Dividen, Kebijakan Utang dan Kepemilikan Manajerial Terhadap Nilai Perusahaan. Diponegoro Journal Of Accounting. 2(2), h: 1-10.

Keuangan ( Studi Pada Perusahaan go Public Sektor Manufaktur) Jurnal Simposium Nasional Akuntansi X. Makasar.

Martalina, Lifessy. (2011) . Pengaruh Profitabilitas dan Ukuran Perusahaan Terhadap Nilai Perusahaan dengan Struktur Modal sebagai Variabel Intervening.

Mirza Chayatun Al-Fisah (2016) : Prof memediasi pengaruh struktur terhadap nilai perusahaan properti yang terdaftar di BEI STIESIA Surabaya.

Pandia, Frianto, (2012). Manajemen Dana dan Kesehatan Bank. Cetakan pertama, PT Rineka Cipta, Jakarta.

Ratih Suklimah, (2011). Pemgaruh Good Corporate Governance Terhadap Nilai Perusahaan Dengan Kinerja Keuangan Sebagai Variabel Intervening Pada Perusahaan Peraih The Indonesia Most Truested Company-CGPI. Jurnal Kewirausahaan Vol. 5 No. 2 pp. 1824 ISSN. 1978-4724.

Rika, Nurlaela dan Islakhudin, (2008). Pengaruh Corporate Social Responcibility Terhadap Nilai Perusahaan dengan Prosentase Tingkat Kepemilikan Manajemen sebagai Variabel Moderating. Simposium Nasional Akuntansi XI.

Rio, Rosinta Ria Panggabean, (2012). Pengaruh Good Corporate Governance Terhadap Kinerja Perusahaan. Jakarta: Binus University.

Salvatore, Dominick. (2005). Ekonomi Manajerial dalam Perekonomian Global. Alih Bahasa Ichsan Setyo Budi. Jakarta: Salemba Empat.

Serimbing, Eddy Rismanda. (2005). "Karakteristik Perusahaan dan Pengungkapan Tanggung Jawab Sosial; Studi Empiris pada Perusahaan yang Tercatat di Bursa Efek Jakarta”. Makalah pada Simposium Nasional Akutansi VIII,Solo, 15-16 September 2005.

Setyaningrum, A. N. (2012). Pengaruh Employee Stock Ownership Program ( ESOP) terhadap Kualitas Implementasi Corporate Governance dan Kinerja Perusahaan http://jimfeb. ub.ac.it./ index.php/ jimfeb/ article/view/248 (5 mei 2018). 
Sillagaan, Hamonangan dan Masud. Mahfoedz. (2006). Mekanisme Corporate Governance, Kualitas Laba dan Nilai Perusahaan. Simposium Nasional Akuntansi (SIA) IX Padang.

Sri Zuliarni, (2012). Pengaruh Kinerja Keuangan Terhadap Harga Saham Pada Perusahaan Mining And Mining Service Di Bursa Efek Indonesia (BEI). Jurnal Aplikasi Bisnis vol. 3 no. 1 pp. $36-48$.

Sugiono, (2009), Statistik Untuk Penelitian, Bandung: CV. Alfabeta

Tumirin. (2007). Analisis Penerapan Good Corporate Governance dan Nilai Perusahaan. Jurnal BETA ( Bisnis, Ekonomi, dan Akuntansi) 6.

Ujiantho dan Pramuka , (2007). Mekanisme Corporate Governance Manajemen Laba dan Kinerja Keuangan ( Studi Pada Perusahaan go Public Sektor Manufaktur) Jurnal Simposium Nasional Akuntansi X. Makasar.

Ulum, Ihyaul, (2009). Intellectual Capital. Konsep dan Kajian Empiris, Cetakan Pertama, Graha Ilmu, Yogyakarta.

Yuanita,(2012), Dwi Aji, Yunita (2011), Analisis pengaruh profitabilitas terhadap keputusan. Dampaknya pada nilai keuangan dan industri yang terdaftar di PT.Bursa Efek Indonesia (BEI) tahun 2004-2009, AAT professional journalis.

Zarkasi. M.W. (2008). Good Corporate Governance. Edisi ke-1. Alfabeta. Bandung. 